\title{
Research on the merger of medical security system of urban and rural residents in China
}

\author{
Hong $\mathrm{Ji}^{\mathrm{a}}$, Runtong Zhang ${ }^{\mathrm{b}}$ \\ School of Economics and Management, Beijing Jiaotong University, Beijing, 100044, China \\ amutou_fish@163.com, brtzhang@bjtu.edu.cn
}

\begin{abstract}
The medical security system of urban and rural residents in China mainly include medical insurance system for urban residents and the new rural cooperative medical system (NCMS). This pattern is conditioned by the city-countryside dualization. With the boundaries between urban and rural areas gradually blurred, the differences between town and country should be eliminated urgently. So this article is about the integration of China's medical security system of urban and rural residents: First, analyze the present problems of current health care system based on the using of SPSS and STATA; Then, study on the necessity and feasibility of the integration of medical insurance system for urban residents and NCMS; Finally, put forward some suggestions about the merger of the two medical system.
\end{abstract}

Keywords: medical security system; Urban and rural residents; System integration.

\section{Introduction}

The imbalance of social structure and economic development in urban and rural influence the running of urban resident medical insurance and NCMS, and the two medical system exposed many problems. In early 2016, the State Council issued "the opinions of the integration of urban and rural resident basic medical insurance system" and say that "integrate the basic medical insurance for urban residents and the NCMS, establish a unified basic medical insurance system for urban and rural resident". It means that the new reform direction is unifying the two medical system.

Based on this background, the paper will elaborate the current running situation of Chinese urban and rural resident medical insurance system firstly and point out the problem generated by the two systems in parallel, and then use SPSS and STATA software through the sample test and Theil index method to prove the objective existence of the problem. On the basis of analysis of the necessity and feasibility of the merger of the two systems, the paper will conclude the roadmap of the merger and finally put forward the targeted policy recommendations.

\section{Status and Problems of Chinese urban and rural residents medical insurance system}

\subsection{The running status of the urban and rural residents basic medical insurance system}

NCMS is organized by the government and led farmers to participate in their own voluntary. It raise funds by individual payments, collective support and government investment to solve the medical problems of rural medical insurance system. Its insured object is the rural household registration and the insured residents is required to pay the basic medical insurance premiums to enjoy the corresponding health insurance benefits.

Urban residents' basic medical adopt by government and the funding modalities include the personal contribution and the government subsidy. Basic medical insurance system for urban residents mainly protect the major urban non-employees, its main feature is government-led, wide coverage and reimbursement convenient.

\subsection{The problems of urban resident medical system and the NCMS running in parallel}

(1) Institutional differences cause urban-rural distribution of spending on health care uneven.

Medical insurance for urban residents and the NCMS distinguish by the residents and occupation, their insurance forms, funding levels and the overall level of reimbursement standards are of significant differences, and the level of insurance contributions and the treatment for urban residents 
basic medical insurance are higher than the new rural cooperative medical. As shown in Table 1, from the perspective of the distribution of urban and rural health costs, the medical and health resources flocked to urban seriously. From 2001 to 2013 the gap between urban and rural health expenditure is always between 2-4 times and the gap between urban and rural per capita health expenditure is always between 2-4 times.

Table 1 the comparation of urban and relatively health cost allocation

\begin{tabular}{|c|c|c|c|c|c|c|c|c|}
\hline & \multicolumn{2}{|c|}{ Urban and rural health costs } & \multicolumn{3}{|c|}{ Per capita health expenditure } & \\
\cline { 2 - 9 } & $\begin{array}{c}\text { Total Health } \\
\text { Expenditure (a } \\
\text { hundred } \\
\text { million) }\end{array}$ & $\begin{array}{c}\text { Urban } \\
\text { (a hundred } \\
\text { million) }\end{array}$ & $\begin{array}{c}\text { rural (a } \\
\text { hundred } \\
\text { million) }\end{array}$ & $\begin{array}{c}\text { Urban / } \\
\text { rural }\end{array}$ & $\begin{array}{c}\text { Total per } \\
\text { capita cost } \\
\text { (yuan) }\end{array}$ & $\begin{array}{c}\text { Urban } \\
\text { (yuan) }\end{array}$ & $\begin{array}{c}\text { Rural } \\
\text { (yuan) }\end{array}$ & $\begin{array}{c}\text { Urban } \\
\text { / rural }\end{array}$ \\
\hline 2001 & 5990.61 & 4043.14 & 1947.46 & 2.08 & 393.80 & 841.20 & 244.77 & 3.44 \\
\hline 2002 & 6985.30 & 4956.28 & 2029.02 & 2.44 & 450.75 & 987.07 & 259.33 & 3.81 \\
\hline 2003 & 7918.89 & 5808.03 & 2110.87 & 2.75 & 509.50 & 1108.91 & 274.67 & 4.04 \\
\hline 2004 & 9133.47 & 6850.13 & 2283.34 & 3.00 & 583.92 & 1261.93 & 301.61 & 4.18 \\
\hline 2005 & 8685.82 & 6331.49 & 2354.32 & 2.69 & 662.30 & 1126.36 & 315.83 & 3.57 \\
\hline 2006 & 9923.68 & 7276.09 & 2647.59 & 2.75 & 748.84 & 1248.30 & 361.89 & 3.45 \\
\hline 2007 & 11754.06 & 9193.72 & 2560.34 & 3.59 & 875.96 & 1516.29 & 358.11 & 4.23 \\
\hline 2008 & 14822.43 & 11617.94 & 3204.49 & 3.63 & 1094.52 & 1861.76 & 455.19 & 4.09 \\
\hline 2009 & 17916.12 & 14041.88 & 3874.25 & 3.62 & 1314.26 & 2176.63 & 561.99 & 3.87 \\
\hline 2010 & 19980.36 & 15508.62 & 4471.74 & 3.47 & 1490.06 & 2315.48 & 666.30 & 3.48 \\
\hline 2011 & 24407.97 & 18633.92 & 5774.05 & 3.23 & 1806.95 & 2697.48 & 879.44 & 3.07 \\
\hline 2012 & 28188.03 & 21349.47 & 6838.55 & 3.12 & 2076.67 & 2999.28 & 1064.83 & 2.82 \\
\hline 2013 & 31668.98 & 23644.97 & 8024.00 & 2.95 & 2327.37 & 3234.12 & 1274.44 & 2.54 \\
\hline 2014 & 35312.40 & & & & 2581.66 & & & \\
\hline
\end{tabular}

Table 2 is the total cost comparison between urban and rural sanitation and the corresponding significant sig value was 0.001 less than 0.05 , indicating significant differences between two sets of data, namely there are significant differences in the total cost of the urban and rural health.

Table 2 the Independent Samples Test of Total Health Expenditure

\begin{tabular}{|c|c|c|c|c|c|c|c|c|c|c|}
\hline \multicolumn{11}{|c|}{ Independent Samples Test } \\
\hline & & \multicolumn{2}{|c|}{$\begin{array}{c}\text { Leven's test for } \\
\text { equality of } \\
\text { variances }\end{array}$} & \multicolumn{7}{|c|}{$\mathrm{t}$-test for equality of means } \\
\hline & & \multirow[t]{2}{*}{$\mathrm{F}$} & \multirow{2}{*}{ Sig. } & \multirow[t]{2}{*}{$\mathrm{T}$} & \multirow{2}{*}{ Df } & \multirow{2}{*}{ Sig. } & \multirow{2}{*}{$\begin{array}{l}\text { Mean } \\
\text { difference }\end{array}$} & \multirow{2}{*}{$\begin{array}{c}\text { Std. Error } \\
\text { Differenc } \\
\mathrm{e}\end{array}$} & \multicolumn{2}{|c|}{$\begin{array}{l}\text { 95\% Confidence Interva } \\
1 \text { of the Difference }\end{array}$} \\
\hline & & & & & & & & & Lower & Upper \\
\hline \multirow{2}{*}{$\begin{array}{l}\text { Total } \\
\text { Health } \\
\text { Expen } \\
\text { diture } \\
\text { S }\end{array}$} & $\begin{array}{l}\text { Equal } \\
\text { vari } \\
\text { ances } \\
\text { assum } \\
\text { ed }\end{array}$ & 17.300 & .000 & 4.075 & 24 & .000 & 7779.666 & 1909.149 & 3839.37471 & $\begin{array}{c}11719.95 \\
760\end{array}$ \\
\hline & $\begin{array}{c}\text { Equal } \\
\text { vari } \\
\text { ances } \\
\text { not } \\
\text { assu } \\
\text { med }\end{array}$ & & & 4.075 & $\begin{array}{l}14 . \\
211\end{array}$ & .001 & 7779.666 & 1909.149 & 3690.63233 & $\begin{array}{c}11868.69 \\
998\end{array}$ \\
\hline
\end{tabular}

(2)Institutional differences lead the consumption of urban and rural residents' health level not fair.

The following we calculate by STATA Theil index to measure the health spending gap between urban and rural residents. This article Choice 2011- 2014 health care spending in the provinces of urban and rural residents to measure the health of the consumer level variables. Theil index results in Table 3, it can be seen from the table that the health spending gap among urban and rural is not 
obvious but the gap between urban and rural areas is obviously large. From the available data, the health spending gap between urban and rural areas the proportion accounted for $80 \%-90 \%$ of the total gap indicating that the consumption gap between urban and rural residents' health play an important role in overall health spending gap.

Table 3 Theil index of Chinese urban and rural residents' health consumption gap

\begin{tabular}{|c|c|c|c|c|c|c|}
\hline \multirow{2}{*}{} & \multicolumn{3}{|c}{ Theil index } & \multicolumn{2}{c|}{$\begin{array}{c}\text { Overall health disparities } \\
\text { contribution rate }(\%)\end{array}$} \\
\cline { 2 - 7 } & $\begin{array}{c}\text { among } \\
\text { urban }\end{array}$ & $\begin{array}{c}\text { among } \\
\text { rural }\end{array}$ & $\begin{array}{c}\text { Between } \\
\text { urban and } \\
\text { rual }\end{array}$ & $\begin{array}{c}\text { among } \\
\text { urban }\end{array}$ & $\begin{array}{c}\text { among } \\
\text { rural }\end{array}$ & $\begin{array}{c}\text { Between } \\
\text { urban } \\
\text { and rual }\end{array}$ \\
\hline 2001 & 0.812 & 0.1155 & 15.562 & 4.92 & 0.7 & 94.38 \\
\hline 2002 & 0.6186 & 0.4734 & 13.9702 & 4.11 & 3.14 & 92.75 \\
\hline 2003 & 0.5331 & 0.4165 & 15.5187 & 3.24 & 2.53 & 94.23 \\
\hline 2004 & 0.7883 & 0.0886 & 19.1696 & 3.93 & 0.44 & 95.63 \\
\hline 2005 & 0.9114 & 1.9055 & 16.9988 & 4.6 & 9.62 & 85.78 \\
\hline 2006 & 0.8061 & 1.3452 & 15.48 & 4.57 & 7.63 & 87.8 \\
\hline 2007 & 0.7889 & 1.2083 & 14.8751 & 4.68 & 7.16 & 88.16 \\
\hline 2008 & 1.0501 & 0.5751 & 15.8677 & 6.00 & 3.29 & 90.71 \\
\hline 2009 & 1.0305 & 0.859 & 14.6792 & 6.22 & 5.18 & 88.6 \\
\hline 2010 & 1.3152 & 0.7192 & 15.2444 & 7.61 & 4.16 & 88.23 \\
\hline 2011 & 1.2031 & 0.7985 & 10.8305 & 9.38 & 6.22 & 84.4 \\
\hline 2012 & 1.6102 & 0.5935 & 8.8624 & 14.55 & 5.36 & 80.09 \\
\hline 2013 & 1.6232 & 0.5895 & 9.2367 & 15.87 & 5.05 & 79.08 \\
\hline 2014 & 1.6411 & 0.5683 & 9.3118 & 15.01 & 5.13 & 79.86 \\
\hline
\end{tabular}

NOTE: Theil coefficient true value is small so multiplied by 100 for analysis.

(3)Institutional differences lead to urban and rural medical insurance fund income and expenditure and the level of health insurance is not fair.

Medicare health insurance levels are usually measured by the proportion of the medicare spending and the gross regional product (GDP).The following sample test conducted by an independent SPSS. Due to space reasons, only lists the data analysis of the level of health insurance here.

Table 4 the Independent Samples Test of proportion of expenditure Funds

\begin{tabular}{|c|c|c|c|c|c|c|c|c|c|c|}
\hline \multicolumn{11}{|c|}{ Independent Samples Test } \\
\hline & & \multicolumn{2}{|c|}{\begin{tabular}{|} 
Leven's \\
test for \\
equality \\
of \\
variances
\end{tabular}} & \multicolumn{7}{|c|}{ t-test for equality of means } \\
\hline & & \multirow[t]{2}{*}{$\mathrm{F}$} & \multirow[t]{2}{*}{ Sig. } & \multirow[t]{2}{*}{$\mathrm{T}$} & \multirow[t]{2}{*}{ Df } & \multirow[t]{2}{*}{ Sig. } & \multirow{2}{*}{$\begin{array}{c}\text { Mean } \\
\text { difference }\end{array}$} & \multirow{2}{*}{$\begin{array}{l}\text { Std. Error } \\
\text { Difference }\end{array}$} & \multicolumn{2}{|c|}{$\begin{array}{c}95 \% \text { Confidence Interval of } \\
\text { the Difference }\end{array}$} \\
\hline & & & & & & & & & Lower & Upper \\
\hline $\begin{array}{c}\text { The } \\
\text { proportion }\end{array}$ & $\begin{array}{c}\text { Equal } \\
\text { vari } \\
\text { ances } \\
\text { assumed }\end{array}$ & 0.869 & .355 & -2.623 & 60 & 0.011 & -.00570668 & .00217580 & -.01005893 & -.00135443 \\
\hline $\begin{array}{c}\text { of } \\
\text { expenditure } \\
\text { Funds }\end{array}$ & \begin{tabular}{|c|} 
Equal \\
vari \\
ances \\
not \\
assumed
\end{tabular} & & & -2.623 & 58.478 & 30.011 & -.00570668 & .00217580 & -.01006126 & -.00135210 \\
\hline
\end{tabular}


Table 4 is the variance analysis results between two sets of data analysis, homogeneity of variance test $\mathrm{F}$ value is 0.869 and significance level is $0.355>0.05$ indicating that no significant difference existed between the two groups variance; expenditure comparison between the two funds, the t test value is -2.623 and the corresponding level of significance sig is $0.011<0.05$ indicating that significant differences exist between two sets of data, namely urban residents and rural residents medical insurance level is different, and the town is more than the countryside.

Through the above difference compared to prove the current Medicare appeared inclined in fairness, the new rural cooperative medical insurance for urban residents and the merger is very necessary

\section{Necessity and Feasibility of the merger of the health care system}

\subsection{Necessity of the merger}

Through the analysis in chapter 2, medical insurance for urban residents and the new rural cooperative merger is necessary. Medicare integration can achieve equitable utilization of health services, which have the same service requirements can also use health services, but also in the health care system to achieve equitable funding among different levels of income. The merger can save resources and avoid duplication of insurance management.

\subsection{Feasibility of the merger}

From the political perspective, the health care system is the main content of the merger of urban and rural economic and social development, the government attaches great importance to this work as the focus of people's livelihood, and the merger of the construction of urban and rural medical insurance system has also been incorporated into the government work plan.

From the insured object, they all belong to no employer, no fixed units, there is no fixed salary income people, and most of them are self-employed and informally employed persons. From the collection of policy, the way and the body perspective, whether it is medical insurance for urban residents and new rural cooperative are one-off collection of policy premiums next year and the levying way of both are family insurance unit.

\section{Recommendation of the merger of health care system}

(1) Increase the government fiscal policy and investment

It is necessary to strengthen regional economic development, increase financial subsidies at all levels of government, only the government give more help to make health services more perfect, to build a sound health care system, to bring better services for urban and rural residents

(2) Establish multi-range of payment standards and standards of treatment

In the process of implementation of the merger of the health insurance system, the payment standards and standards of treatment can be made of multi-file that under the same institutional framework, residents can enjoy the corresponding level of medical treatment so that urban and rural residents have more right to choose.

(3) Introducing private sector participation to make economic and social benefits win-win

By introducing commercial insurance companies resume company partnerships may be formed multi-subject insured, hospitals, government, insurance companies and other win-win situation, the integration of urban and rural medical security system should be widely introduced in the private sector to participate and thus the pattern of cooperative competition mechanism of multiple subjects can be formed.

\section{Acknowledgments}

Thanks for the project "The Wise Medical Health Management Innovation Driven by Big-data" (Project No.71532002) which is supported by the NSFC (National Natural Science Foundation of China). 


\section{References}

[1] Min Jiang. Discussion on the merger of the new rural cooperative medical insurance system and the urban resident medical system [J]. Human Resource Management, 2013(6):234-234.

[2] Gongcheng Zheng. Nine key points of urban and rural medical insurance system integration [J]. China Medical Insurance, 2013(6):9-12.

[3] Xiangyu Cheng. A Summary of Integration of urban and rural basic medical insurance [J]. China Health Policy Research, 2012, 05(9):58-61.

[4] Ping Shao. Measurement and analysis of the level of health protection [J]. China Health Economics, 2012, 31(02):17-19.

[5] Liping Mei, Yulin Qiu. Summary of urban and rural medical insurance research [J]. China Health Economics, 2009, 28(8):37-39. 